\title{
Pharmacokinetics and Safety in Rhesus Monkeys of a Monoclonal Antibody-GDNF Fusion Protein for Targeted Blood-Brain Barrier Delivery
}

\author{
William M. Pardridge ${ }^{1,2}$ and Ruben J. Boado ${ }^{1}$
}

Received May 10, 2009; accepted July 6, 2009; published online July 17, 2009

\begin{abstract}
Purpose. Glial-derived neurotrophic factor (GDNF) is a potential therapy for stroke, Parkinson's disease, or drug addiction. However, GDNF does not cross the blood-brain barrier (BBB). GDNF is re-engineered as a fusion protein with a chimeric monoclonal antibody (MAb) to the human insulin receptor (HIR), which acts as a molecular Trojan horse to deliver the GDNF across the BBB. The pharmacokinetics (PK), toxicology, and safety pharmacology of the HIRMAb-GDNF fusion protein were investigated in Rhesus monkeys.

Methods. The fusion protein was administered as an intravenous injection at doses up to $50 \mathrm{mg} / \mathrm{kg}$ over a $60 \mathrm{~h}$ period to 56 Rhesus monkeys. The plasma concentration of the HIRMAb-GDNF fusion protein was measured with a 2-site sandwich ELISA.

Results. No adverse events were observed in a 2-week terminal toxicology study, and no neuropathologic changes were observed. The PK analysis showed a linear relationship between plasma AUC and dose, a large systemic volume of distribution, as well as high clearance rates of $8-10 \mathrm{~mL} / \mathrm{kg} / \mathrm{min}$.

Conclusions. A no-observable-adverse-effect level is established in the Rhesus monkey for the acute administration of the HIRMAb-GDNF fusion protein. The fusion protein targeting the insulin receptor has a PK profile similar to a classical small molecule.
\end{abstract}

KEY WORDS: blood-brain barrier; insulin receptor; GDNF; primate; Trojan horse.

\section{INTRODUCTION}

Glial-derived neurotrophic factor (GDNF) is a potential neurotherapeutic for both acute and chronic brain disease (1-3). The acute intra-cerebral injection of GDNF reduces the stroke volume in experimental ischemia (4). The neurotrophin must be administered to brain via a trans-cranial route, because GDNF does not cross the blood-brain barrier (BBB) (5). The chronic administration of GDNF could be therapeutic in both Parkinson's disease (PD), as well as drug or alcohol addiction $(6,7)$. The trans-cranial injection of GDNF to humans with PD was not therapeutic (8), because the GDNF did not reach the target site (9), despite the direct pumping of the neurotrophin into the human brain. The BBB is the limiting factor in the CNS drug development of GDNF, or other recombinant proteins (10).

GDNF can be made transportable through the human $\mathrm{BBB}$ by re-engineering the neurotrophin as a fusion protein with a BBB molecular Trojan horse (4). The latter is an endogenous peptide, or a peptidomimetic monoclonal antibody (MAb) against a receptor-mediated transcytosis system within the BBB (11). The most potent molecular Trojan horse is a MAb against the human insulin receptor (HIR) (12). Prior work described the genetic engineering, transient expression, and biochemical validation of a HIRMAb-GDNF fusion protein (4). Following fusion of the amino terminus of the

\footnotetext{
${ }^{1}$ ArmaGen Technologies, Inc., 914 Colorado Ave., Santa Monica, California 90401, USA.

${ }^{2}$ To whom correspondence should be addressed. (e-mail: wpardridge@ armagen.com)
}

mature human GDNF to the carboxyl terminus of the heavy chain of the HIRMAb, the HIRMAb-GDNF retained high affinity binding for both the HIR, to mediate transport across the $\mathrm{BBB}$, and to the GDNF receptor (GFR)- $\alpha 1$, to mediate pharmacologic action in brain behind the BBB (4). The biological activity of the HIRMAb-GDNF was equivalent to that of recombinant GDNF, and the stroke volume was reduced $90 \%$ by the acute administration of the HIRMAbGDNF fusion protein in experimental ischemia (4).

The present studies were designed to support a phase I, first-in-human, dose-escalation clinical trial. These nonclinical studies were performed in the Rhesus monkey to evaluate the pharmacokinetics (PK), safety, tolerability, and tissue crossreactivity of this first in class recombinant fusion protein. The Rhesus monkey was chosen as the experimental model system, because the HIRMAb cross reacts with the insulin receptor of Old World primates, but not New World primates or rodents (12). Moreover, there is no known MAb against the rodent insulin receptor that could be used as a BBB molecular Trojan horse. The route of administration, intravenous (IV) bolus injection, used in these studies was chosen because this is the intended route of administration in initial human trials.

\section{MATERIALS AND METHODS}

\section{Production of CHO Line}

A high producing eukaryotic host cell line was engineered for manufacturing of the HIRMAb-GDNF fusion 
protein. A tandem vector was engineered wherein the expression cassettes for the heavy chain fusion gene, the light chain gene, and the murine dihydrofolate reductase (DHFR) gene were placed as tandem units on a single strand of DNA, as described previously (13). DG44 Chinese hamster ovary (CHO) cells, adapted to serum-free medium, were electroporated with the tandem vector, were selected with G418 and hypoxanthine-thymine deficient medium, and were amplified with methotrexate treatment. The $\mathrm{CHO}$ line was subjected to two rounds of dilutional cloning at one cell/well, and positive clones were selected with measurement of medium human IgG concentrations by enzyme-linked immunosorbent assay (ELISA). The CHO line was stable through multiple generations and produced medium $\mathrm{IgG}$ levels of 10 $20 \mathrm{mg} / \mathrm{L}$ in shake flasks at a cell density of 1-2 million cells/mL in serum-free medium (SFM). The DG44 CHO cell line permanently transfected with the HIRMAb-GDNF gene was made in-house and designated the CHO-HIRMAb-GDNF line.

\section{Manufacturing and Analysis}

The HIRMAb-GDNF fusion protein was manufactured in a setting that could be replicated in future Good Manufacturing Practice (GMP) production for clinical trials. A $50 \mathrm{~L}$ Wave bioreactor was seeded with the CHOHIRMAb-GDNF cells, and the medium was expanded to 23.5 L. The bioreactor was maintained for approximately 3 weeks in perfusion mode, where approximately $20 \mathrm{~L}$ of SFM was perfused and collected each day. The cell density reached 30 million cells $/ \mathrm{mL}$, and the medium $\mathrm{IgG}$ was approximately $100 \mathrm{mg} / \mathrm{L}$. Approximately $400 \mathrm{~L}$ of conditioned medium was concentrated 10 -fold with tangential flow filtration, and the HIRMAb-GDNF fusion protein was purified by sequential protein A affinity chromatography, cation exchange chromatography, anion exchange chromatography, nano-filtration, and final diafiltration against $0.01 \mathrm{M}$ sodium acetate $/ 0.14 \mathrm{M} \mathrm{NaCl} / \mathrm{pH}=5.5$ (ABS) buffer. The yield of HIRMAb-GDNF fusion protein in the final drug product was $5 \mathrm{~g}$ of protein from the $23.5 \mathrm{~L}$ bioreactor. $\mathrm{CHO}$ host protein was $<1$ parts per million (PPM), as determined by ELISA (Cygnus Technologies, Southport, NC); protein A was $<4$ PPM, as determined by ELISA (Cygnus Technologies); DNA was $<0.001$ PPM as determined by real time PCR using CHO cell DNA as the assay standard; endotoxin was $<0.1$ EU/mg protein, as determined by the limulus amebocyte lysate assay (Lonza Biologics, Portsmouth, NH); and the bioburden was $<1$ colony forming unit $/ \mathrm{mL}$ (Bioreliance, Rockville, MD). The final product was a clear, colorless solution of $6.5 \mathrm{mg} / \mathrm{mL}$ and conformed to specifications with regard to identity (human IgG and GDNF Western blotting), potency (HIR binding affinity, GDNF receptor- $\alpha 1$ binding affinity), purity [sodium dodecylsulfate polyacrylamide gel electrophoresis (SDS-PAGE), size exclusion high performance liquid chromatography], and glycosylation analysis (neutral monosaccharide, N-terminal oligosaccharide, Charles River, Malvern, PA). Assays to assess GFR $\alpha 1$ binding and cret kinase activation using a human neural cell line were described previously (4). The protein was stable as a sterile liquid stored at $4 \mathrm{C}$ for at least 1 year. The final concentration of the HIRMAb-GDNF fusion protein that was injected into primates was confirmed by UV absorption spectrophotometry (MPI Research, Mattawan, MI).

\section{Housing of Animals}

Rhesus monkeys (Macaca mulatta) of mixed sex were used for all studies and were housed at MPI Research, Inc. (Mattawan, MI) in stainless steel cages in a controlled environment (18 to $28^{\circ} \mathrm{C}$ and $30-70 \%$ relative humidity) on a 12-h light/dark cycle. Lab Diet Certified Primate Diet (PMI Nutrition International) was provided twice daily. Tap water was provided ad libitum. All aspects of the primate study performed at MPI Research was conducted in strict compliance with the United States Food and Drug Administration (FDA) Good Laboratory Practice (GLP) Regulations, 21 CFR Part 58. All procedures were in compliance with the Animal Welfare Act Regulations and were approved by the Institutional Animal Care and Use Committee.

\section{In vivo Study Design}

\section{Dose Selection}

The animals were treated with either $0,0.4,2$, or $10 \mathrm{mg} /$ $\mathrm{kg}$ of the HIRMAb-GDNF fusion protein administered as a slow bolus intravenous injection over a 2 -min period. In the 2-week toxicity study, the doses were administered every $12 \mathrm{~h}$ for five consecutive doses over a 60-hr period, with a total dosing of $0,2,10$, and $50 \mathrm{mg} / \mathrm{kg}$.

\section{2-Week Toxicity Study}

The initial clinical application of the HIRMAb-GDNF fusion protein is projected to be as a single IV administration within the first $5 \mathrm{~h}$ of an acute ischemic stroke. Therefore, a 2-week toxicity study in the Rhesus monkey was designed. For the repeat-dose, 2-week toxicity study, young adult, experimentally naïve male and female Rhesus monkeys, 2.8-3.3 kg body weight, were assigned to one of four treatment groups: (a) Group 1: 10 monkeys (5 male, 5 female) were administered the ABS control article; (b) Group 2: 6 monkeys (3 male, 3 female) were administered a total of $2.0 \mathrm{mg} / \mathrm{kg}$ HIRMAb-GDNF fusion protein; (c) Group 3: 6 monkeys (3 male, 3 female) were administered a total of $10.0 \mathrm{mg} / \mathrm{kg}$ of HIRMAb-GDNF fusion protein; and (d) Group 4: 10 monkeys (5 male, 5 female) were administered a total of $50.0 \mathrm{mg} / \mathrm{kg}$ HIRMAb-GDNF fusion protein. In groups 1 and 4 , a total of 4 monkeys ( 2 males, 2 females) were euthanized 1 day after the final of five doses of the test or control article. The remaining animals were euthanized on day 13 of the study period. A complete physical exam, and opthalmoscopic exam, and electrocardiogram (ECG) were conducted on all animals pre-test and prior to euthanasia. Cageside observations were made twice per day, and a detailed clinical exam was performed on each animal $1 \mathrm{hr}$ post-dose. Body weights were measured pre-test and twice a week during the study. Food consumption was measured daily during the study. Clinical pathologic examinations were performed pretest and prior to euthanasia, and included urinalysis, coagulation tests (prothombin, activated partial thromboplastin time), hematologic profile, chemistry panel (sodium, potassium, chloride, 
calcium, phosphorous, total bilirubin, urea nitrogen, creatinine, total protein, albumin, globulin, triglyceride, cholesterol, glucose, aspartate aminotransferase, alanine aminotransferase, gamma glutamyl transferase, and sorbitol dehydrogenase). Organ weights were determined at necropsy for brain and peripheral organs (adrenal, epididymis, heart, kidney, liver, lung, ovary, pituitary, spleen, testis, thymus, and thyroid/ parathyroid). Hematoxylin and eosin microscopic analysis was performed for these organs and 35 other peripheral organs. Brain (cerebrum, midbrain, cerebellum, medulla/pons) was evaluated by glial fibrillary acid protein (GFAP) immunocytochemistry, and by fluoro Jade B fluorescence microscopy. The primate brain was sectioned and paraffin-blocked into 9 blocks/brain, as described by Garman (14). The brain was fixed by head-only perfusion fixation with $10 \%$ neutral buffered formalin. Blood $(1 \mathrm{~mL})$ was removed from the femoral vein and collected in tubes with K2-EDTA at 0, 2, 5, 30, $60 \mathrm{~min}, 2,4,23 \mathrm{hrs}$, and at day 13 after the first IV injection of the HIRMAb-GDNF fusion protein. Cerebrospinal fluid (CSF) was removed via the cisterna magna at 0,3 , 23, and $47 \mathrm{hrs}$ after the first IV injection of the HIRMAbGDNF fusion protein.

\section{Single-Dose Safety Pharmacology Study}

Young adult male Rhesus monkeys (body weight 3.4$4.8 \mathrm{~kg}$ ) were assigned to four treatment groups (6 monkeys/ group), and were administered $0,0.4,2.0$, or $10.0 \mathrm{mg} / \mathrm{kg}$ of HIRMAb-GDNF fusion protein by slow IV bolus injection over 2 min on day 1. Animals were observed for changes in cardiovascular, respiratory, and central nervous system (CNS) function. The cardiovascular and pulmonary components of the study were performed sequentially in 2 phases. Within each phase, animals were treated and then given a 7-day washout period before the next dose and phase. Both phases and each treatment were conducted in the same four groups of 6 monkeys per treatment group. All measurements were made in conscious animals with surgically implanted telemetry transmitter devices. For the cardiovascular study, body temperature, blood pressure (systolic, diastolic, mean), heart rate, and ECG were monitored via telemetry for at least $2 \mathrm{~h}$ before dosing and at least $20 \mathrm{~h}$ post-dosing. ECG parameters included the QRS duration, the PR, RR, QT intervals, and heart rate-corrected QT intervals. The data were collected in 1-minute frames and reported in 15-minute intervals. Cardiac troponin levels were measured at the end of monitoring and all values were $<0.05 \mathrm{ng} / \mathrm{mL}$. Arterial blood samples were removed at $0,0.5,1,2$, and $4 \mathrm{hr}$ post-dose for measurement of $\mathrm{pH}, \mathrm{pCO} 2, \mathrm{pO} 2$, bicarbonate, and CO-oximetry measurements. For pulmonary testing, the animals were placed in restraint chairs and fitted with a helmet for monitoring respiration. A continuous flow of air was supplied and removed from the helmet at a constant rate. A sampling line was attached to the top of the helmet and connected to a pressure transducer. Measured pulmonary parameters included the respiratory rate, tidal volume, and minute volume, and were monitored for $30 \mathrm{~min}$ pre-dose and $3.5 \mathrm{~h}$ post-dose. The data were collected in 1-minute frames and reported in 15-minute intervals. Detailed neurobehavioral functional observational battery (FOB) measurements were made coincident with the pulmonary testing at pretest, 4 hrs post- dose, and 24 hrs post-dose. A modified FOB assessment was made pre-dose and 75 min post-dose while the animal was placed in the restraint chair, and included assessment of mental status, lacrimation, salivation, gross motor movements, cranial nerve function, and motor strength.

\section{ELISA}

\section{Immunoreactive HIRMAb-GDNF Fusion Protein}

The concentration of the HIRMAb-GDNF fusion protein in plasma and CSF was measured with a 2-site sandwich ELISA, using the HIR ECD as the capture reagent, and an anti-GDNF antibody as the detector reagent. The assay was designed so that immunoreactivity would be measured only on the intact HIRMAb-GDNF fusion protein, and requires the presence of both parts of the fusion protein, the HIRMAb moiety and the GDNF moiety, in order to measure a positive signal. A murine MAb against the HIR (ab36550, Abcam, Cambridge, MA) was plated in 96-well plates overnight at $4 \mathrm{C}$ in $0.1 \mathrm{M} \mathrm{NaHCO} / 8.3$ (100 ng/well); this antibody binds an epitope on the HIR that is spatially removed from the HIRMAb binding site. The solution was removed by aspiration, the wells were washed with $0.01 \mathrm{M}$ Tris/0.15 M $\mathrm{NaCl} / 7.4$ (TBS), and $100 \mathrm{uL}(200 \mathrm{ng}) /$ well of lectin affinity purified HIR extracellular domain (ECD) was added followed by a 90 min incubation at room temperature (RT). The wells were washed with TBS $/ 0.05 \%$ Tween-20 (TBST), and either the sample or the HIRMAb-GDNF reference standard was added in $100 \mathrm{uL} /$ well followed by a $60 \mathrm{~min}$ incubation at RT. A goat anti-human GDNF antibody (\#AF-212-NA, R\&D Systems, Minneapolis, MN) was applied in a volume of $100 \mathrm{uL}(400 \mathrm{ng}) /$ well, followed by a $30 \mathrm{~min}$ incubation at RT. Following washing with TBST, a conjugate of rabbit anti-goat IgG and alkaline phosphatase (\#AP-5000, Vector Labs, Burlingame, CA) was applied in a volume of $100 \mathrm{uL}$ (500 ng)/well followed by a $45 \mathrm{~min}$ incubation at RT. The wells were washed with TBST, and $100 \mathrm{uL} /$ well of p-nitrophenylphosphate (\#P5994, Sigma Chemical Co., St. Louis, MO) was incubated in the dark at RT for $15-30 \mathrm{~min}$. The color development was terminated by the addition of $100 \mathrm{uL} /$ well of $1.2 \mathrm{M} \mathrm{NaOH}$, and color development was measured with an ELISA plate reader at $405 \mathrm{~nm}$. The limit of detection was $1 \mathrm{ng} /$ well of HIRMAb-GDNF fusion protein. The standard curve was determined with $0-300 \mathrm{ng} / \mathrm{mL}$ solutions of HIRMAb-GDNF fusion protein and was curvilinear, which was fit with a non-linear regression analysis using the WinNonlin software (Pharsight, Mountain View, CA). The curve fitting yielded a correlation coefficient $\left(r^{2}\right)$ of $>0.97$. Accuracy was confirmed by spiking control Rhesus monkey plasma with 10 $100 \mathrm{ng} / \mathrm{mL}$ concentrations of the HIRMAb-GDNF fusion protein. The intra-assay coefficient of variation $(\mathrm{CV})$ and the inter-assay $\mathrm{CV}$ were $<15 \%$. Assay specificity was demonstrated by showing that high concentrations $(10,000 \mathrm{ng} / \mathrm{mL})$ of either the HIRMAb or human IgG1 caused no reaction in the ELISA.

\section{Anti-HIRMAb-GDNF Antibody Response}

The presence of anti-HIRMAb-GDNF antibodies in monkey plasma was detected with a 2-site sandwich ELISA, 
using either the HIRMAb or the HIRMAb-GDNF fusion protein as the capture reagent and biotinylated HIRMAbGDNF fusion protein as the detector reagent. As a positive control, a rabbit anti-HIRMAb-GDNF antiserum was prepared at Prosci, Inc. (Poway, CA). The rabbit anti-HIRMAbGDNF antisera and the respective preimmune rabbit sera were diluted in 0.01 M NaHPO4/0.15 M NaCl/7.4 (PBS). The chimeric HIRMAb, without the fused GDNF, or the HIRMAb-GDNF fusion protein was plated overnight at 4C in 96wells in $100 \mathrm{uL}(250 \mathrm{ng}) /$ well in $0.05 \mathrm{M} \mathrm{NaHCO} 3 / 8.3$. The wells were blocked with PBS containing $1 \%$ bovine serum albumin (PBSB), followed by the addition of $100 \mathrm{uL} /$ well of a 1:50 dilution of Rhesus monkey plasma or various dilutions of the rabbit anti-HIRMAb-GDNF antisera diluted in PBS. After a 60 min incubation at 37C, the wells were washed with PBSB, and the wells were incubated with biotinylated HIRMAb-GDNF fusion protein $(1.25 \mathrm{ug} / \mathrm{mL})$ for $60 \mathrm{~min}$. The wells were washed with PBSB, followed by incubation with $100 \mathrm{uL}(500 \mathrm{ng}) /$ well of a streptavidin-peroxidase conjugate (\#SA-5004, Vector Labs) for $30 \mathrm{~min}$ at RT. The wells were washed with PBSB, and $100 \mathrm{uL} /$ well of o-phenylenediamine $/ \mathrm{H}_{2} \mathrm{O}_{2}$ developing solution (\#P5412, Sigma) was added for a $20 \mathrm{~min}$ incubation in the dark at RT. The reaction was stopped by the addition of $100 \mathrm{uL} /$ well of $1 \mathrm{M} \mathrm{HCl}$, followed by the measurement of absorbance at $492 \mathrm{~nm}$ and $650 \mathrm{~nm}$. The A650 was subtracted from the A492. The (A492-A650) for the PBSB blank was then subtracted from the (A492-A650) for the sample.

\section{Pharmacokinetics Analysis}

The rate of removal from plasma of the HIRMAb-GDNF fusion protein was examined following acute administration to Rhesus monkeys. The serum concentration of immunoreactive HIRMAb-GDNF fusion protein $(\mathrm{ng} / \mathrm{mL})$ was divided by the injection dose (ID) to compute the $\% \mathrm{ID} / \mathrm{mL}$, and this data was fit to a 2-exponential equation: $\% \mathrm{ID} / \mathrm{mL}=\mathrm{A} 1 \mathrm{e}^{-\mathrm{k} 1 \mathrm{t}}+$ $\mathrm{A} 2 \mathrm{e}^{-\mathrm{k} 2 \mathrm{t}} ; \mathrm{A} 1$ and $\mathrm{A} 2$ are the intercepts, and $\mathrm{k} 1$ and $\mathrm{k} 2$ are the slopes of each exponential function. These values were used to compute the pharmacokinetics (PK) parameters, including the mean residence time (MRT), the central volume of distribution $(\mathrm{Vc})$, the extra-vascular volume of distribution (Vss), the area under the concentration curve (AUC), and the systemic clearance (CL), as described previously (12). The residual sum of squares ranged from 0.139 to 0.164 , and the standard deviation of each estimate ranged from $8-20 \%$ of the respective mean for all estimated parameters. The nonlinear regression analysis was performed with the PAR program of the BMDP2007 Statistical Software package (Statistical Solutions, Dublin, Ireland).

\section{Tissue-Cross Reactivity}

\section{Biotinylation of HIRMAb-GDNF}

A biotinylated form of the HIRMAb-GDNF fusion protein was produced for 2 applications: (i) a sandwich ELISA measuring the formation of antibodies against the fusion protein in primate plasma, and (ii) the tissue crossreactivity study. The HIRMAb-GDNF fusion protein $(1.0 \mathrm{~mL}$ of $6.6 \mathrm{mg} / \mathrm{mL}$ in ABS buffer) was biotinylated with $65 \mathrm{uL}$ of
$15 \mathrm{mg} / \mathrm{mL}$ sulfo biotin-LC-LC-N-hydroxysuccinimide, where LC = long chain (\#21338, Pierce Chemical Co., Rockford, IL) by rocking $60 \mathrm{~min}$ at RT. The solution was transferred to an Ultra-15 micro-concentrator (Millipore, Boston, MA) for buffer exchange in ABS buffer and removal of the unreacted biotin reagent. As a negative control, human IgG1/kappa (\#I5154, Sigma) was similarly biotinylated. The biotinylation of the HIRMAb-GDNF fusion protein, or the human IgG1, was confirmed by SDS-PAGE and Western blotting, where the blot was probed with a mixture of avidin and biotinylated peroxidase. The control HIRMAb-GDNF fusion protein, or the control human IgG1, gave no reaction in the Western blot, whereas the biotinylated protein was strongly visualized at the appropriate molecular size for both heavy chain and light chain. The effect of biotinylation on the HIRMAbGDNF fusion protein binding to the HIR ECD was measured by ELISA, as described previously (4). The biotinylated HIRMAb-GDNF fusion protein bound with high affinity to the HIR ECD with an ED50 of $0.69 \pm 0.13 \mathrm{nM}$. The effect of biotinylation on the HIRMAb-GDNF fusion protein binding to the GFR $\alpha 1$ ECD was measured by ELISA, as described previously (4). The biotinylated HIRMAb-GDNF fusion protein bound with high affinity to the GFR $\alpha$ l with an ED50 of $2.4 \pm 0.7 \mathrm{nM}$.

\section{Immunocytochemistry}

A Tissue-cross reactivity (TCR) study of the HIRMAbGDNF fusion protein was performed with autopsy, archival tissues from 3 healthy humans and 2 healthy Rhesus monkeys using the avidin-biotin immunoperoxidase method under GLP conditions by Charles River Laboratories Pathology Associates (Frederick, MD). Fresh tissue was frozen in cryomolds in Optimal Cutting Temperature (OCT) compound, and frozen sections (5 micron) were prepared with a cryostat. A total of 35 human and 34 Rhesus monkey organs were examined as required by the FDA (15). The sections were fixed in acetone for $10 \mathrm{~min}$ and in $10 \%$ buffered formalin for $10 \mathrm{sec}$ just prior to staining. The primary antibody was either the biotinylated HIRMAb-GDNF fusion protein, or biotinylated human $\mathrm{IgG1}$, used at a concentration of 2 or $15 \mathrm{ug} / \mathrm{mL}$. Following washing, the slides were exposed to avidin and biotinylated peroxidase (ABC Elite, Vector Labs, Burlingame, CA). No secondary antibody was required since the primary antibody was biotinylated. The chromagen was diaminobenzidine. Positive tissue staining was verified with an anti- $\alpha_{2}$-microglobulin antibody. Specificity for the HIR was examined with spot slides using recombinant HIR (R\&D Systems) and human parathyroid hormone-related protein (PTHrP)-1-34 (Sigma Chemical Co.).

\section{Statistical Analysis}

Statistical significance was determined at the $p<0.05$ level using the analysis of variance (ANOVA) with Bonferroni correction.

\section{RESULTS}

The 32 Rhesus monkeys in the multiple-dose, 2-week terminal toxicity study were administered $0,0.4,2.0$, or 
$10.0 \mathrm{mg} / \mathrm{kg}$ of the HIRMAb-GDNF fusion protein every $12 \mathrm{~h}$ for 5 consecutive doses, or $0,2,10$, or $50 \mathrm{mg} / \mathrm{kg}$ of the fusion protein. Administration of the study drug was associated with no deaths, no clinical findings, no change in food intake, no change in body or organ weights, and no change in 40 clinical pathology blood or urine tests (Methods). There was no change in glycemic control in any of the four treatment groups (Fig. 1). There were no macroscopic or microscopic changes in peripheral organs, and no macroscopic or microscopic changes in the brain (cerebrum, cerebellum, spinal cord), based on hematoxylin \& eosin staining, GFAP immunocytochemistry, or fluoro Jade B fluorescence microscopy. An additional 24 Rhesus monkeys were evaluated in a single-dose safety pharmacology study, which showed no changes in continuous ECG telemetry, pulmonary function tests, arterial blood gases, or neurobehavioral functional observational battery. No increases in cardiac troponin I in plasma were detected.

A 2-site sandwich ELISA was developed for the measurement of immunoreactive HIRMAb-GDNF fusion protein in plasma and CSF. The structure of the assay is shown in Fig. 2A, which shows that the HIR ECD is used as the capture reagent, and an anti-GDNF antibody is used as the detector reagent. Therefore, the assay only measures intact HIRMAb-GDNF fusion protein, and does not detect the HIRMAb without the attached GDNF (Methods). The spiking of control Rhesus monkey plasma with known concentrations of the HIRMAb-GDNF reference standard yielded a linear increase in the concentration of fusion protein detected by the assay (Fig. 2B). The time-dependent changes in plasma concentration of the HIRMAb-GDNF fusion protein is shown in Table I following the IV injection of $0.4,2$, or $10 \mathrm{mg} / \mathrm{kg}$ of the fusion protein. The plasma concentration curves shown in Table I were fit to a 2-exponential PK model (Methods) to yield the PK parameters in Table II. The PK profile was linear, as there was a linear relationship between plasma AUC and dose of HIRMAb-GDNF fusion protein (Fig. 3). The fusion protein was rapidly cleared by tissues in vivo as the systemic clearance was $8-10 \mathrm{~mL} / \mathrm{kg} / \mathrm{min}$ (Table II). The extravascular volume of distribution, Vss, was large, 3000$6000 \mathrm{~mL} / \mathrm{kg}$, and was more than 10-fold greater than the central volume of distribution, Vc (Table II). The CSF level was below

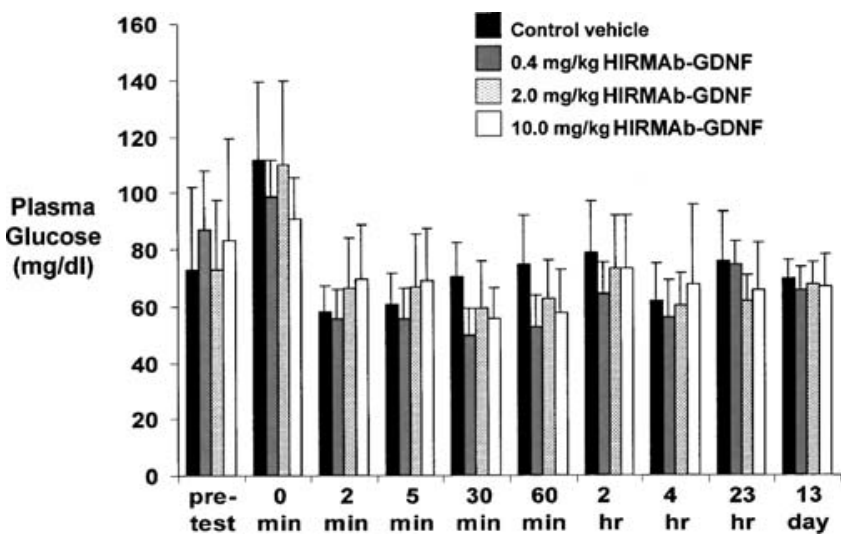

Fig. 1. Plasma glucose in 4 treatment groups of Rhesus monkeys at the pre-test, and various times after the bolus IV injection of $0-10 \mathrm{mg} /$ $\mathrm{kg}$ of the HIRMAb-GDNF fusion protein. Data are mean \pm S.D. $(n=$ 6-10 animals per group). There are no significant changes in plasma glucose among the treatment groups.
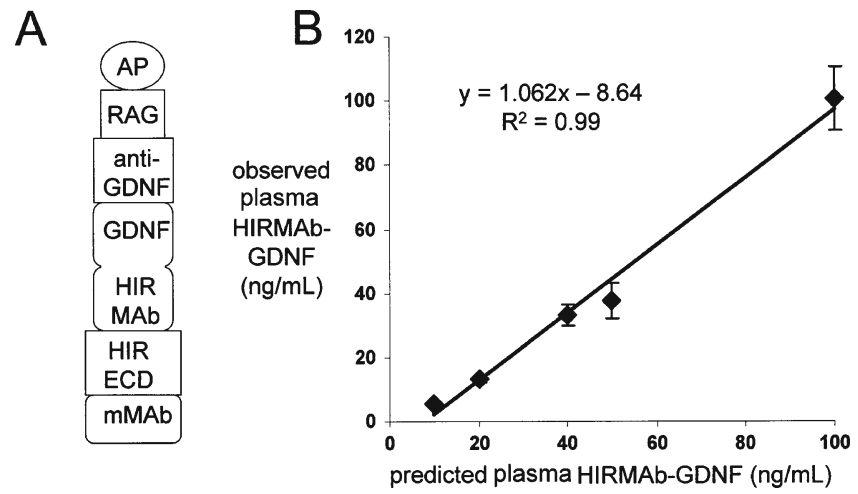

Fig. 2. (A) Structure of the 2-site ELISA used to measure the concentration of the HIRMAb-GDNF fusion protein. A mouse monoclonal antibody (mMAb) against the HIR is plated, which captures the HIR ECD derived from CHO cells. The HIRMAb part of the fusion protein binds the HIR ECD, and the GDNF part of the fusion protein is bound by a goat anti-GDNF antibody, which is bound by a conjugate of a rabbit anti-goat (RAG) antibody and alkaline phosphatase (AP). (B) Control Rhesus monkey plasma was spiked with 5 different doses of the HIRMAb-GDNF reference standard. There is a linear correlation between the observed concentration and the predicted concentration of fusion protein.

the limit of detection except in the high dose group. The CSF concentration of the HIRMAb-GDNF fusion protein was 1.2 \pm $0.6,3.0 \pm 1.1$, and $3.6 \pm 0.9 \mathrm{ng} / \mathrm{mL}($ mean $\pm \mathrm{SE}, n=10)$ at 3,23 , and $47 \mathrm{~h}$ after injection, respectively. There was no change in the total protein content of the CSF in any group at any time relative to the control group.

A 2-site sandwich ELISA was developed to measure the formation of antibodies against the HIRMAb-GDNF fusion protein, and the structure of the ELISA is outlined in Fig. 4A. Owing to the bivalency of antibody binding, the anti-fusion protein antibody binds both the HIRMAb-GDNF capture reagent and the biotinylated HIRMAb-GDNF detector reagent (Fig. 4A). As a positive control, a rabbit antiHIRMAb-GDNF antiserum and a respective pre-immune serum were tested for reactivity at dilutions ranging from 1:30 to $1: 100,000$. The pre-immune serum gives no reaction in the assay, whereas the rabbit antiserum is strongly reactive (Fig. 4B). The antiserum reactivity in the ELISA was somewhat higher when the HIRMAb was used as the capture reagent, as opposed to the HIRMAb-GDNF fusion protein (Fig. 4B). Reaction above the pre-immune level is observed at 1:100,000 dilutions, and the dilution that gives $50 \%$ of the maximal titer is approximately 1:2,000 (Fig. 4B). The immune signals for a 1:50 dilution of terminal primate plasma are shown in Fig. 4C for 24 Rhesus monkeys. Only monkeys in the highest 2 dose groups show any immune response at 13 days following five consecutive doses of the HIRMAb-GDNF fusion protein over a 60 -h period at days $1-3$, and only $25 \%$ of these monkeys showed an immune response producing an ELISA signal above a cutoff of 0.3 (Fig. 4C).

Biotinylated HIRMAb-GDNF gave strong staining on spot slides of human insulin receptor, but did not react with spot slides of human PTHrP. The biotinylated hIgG1 did not react with either protein on spot slides. Biotinylated human IgG1 did not react with any human or Rhesus monkey tissue sections at 2 or $15 \mathrm{ug} / \mathrm{mL}$, although all tissues stained with an antibody to human $\beta 2$-microglobulin. The tissue 
Table I. HIRMAb-GDNF Fusion Protein Plasma Concentrations in Rhesus Monkeys

\begin{tabular}{cccc}
\hline & \multicolumn{3}{c}{$\mathrm{ng} / \mathrm{mL}$} \\
\cline { 2 - 4 } minutes & $0.4 \mathrm{mg} / \mathrm{kg}$ & $2.0 \mathrm{mg} / \mathrm{kg}$ & $10.0 \mathrm{mg} / \mathrm{kg}$ \\
\hline 2 & $1,356 \pm 128$ & $7,625 \pm 598$ & $39,139 \pm 7,524$ \\
5 & $772 \pm 139$ & $4,005 \pm 503$ & $10,787 \pm 1,174$ \\
30 & $121 \pm 21$ & $532 \pm 70$ & $1,246 \pm 147$ \\
60 & $100 \pm 18$ & $395 \pm 38$ & $1,048 \pm 78$ \\
120 & $52 \pm 9$ & $212 \pm 28$ & $661 \pm 100$ \\
240 & $46 \pm 10$ & $188 \pm 22$ & $635 \pm 104$ \\
1380 & $3.7 \pm 2.5$ & $35 \pm 6$ & $156 \pm 44$ \\
\hline
\end{tabular}

Mean \pm SE $(n=6-10)$.

staining with the biotinylated HIRMAb-GDNF was stronger at $15 \mathrm{ug} / \mathrm{mL}$, as compared to $2 \mathrm{ug} / \mathrm{mL}$. There was low level staining in virtually all human or primate tissues. The human or primate tissues that yielded frequent, strong staining at $15 \mathrm{ug} / \mathrm{mL}$ are listed in Table III. In the CNS, neurons, glial cells, and endothelium were strongly positive in human tissues. Endothelial staining was strong in the cerebrum, cerebellum, spinal cord, and eye in humans. Epithelial cells and mesothelial cells in diverse tissue in humans and primates yielded strong immunocytochemical staining (Table III). Tissue macrophages also were strongly stained by the biotinylated HIRMAb-GDNF fusion protein at $15 \mathrm{ug} / \mathrm{mL}$. The HIRMAb-GDNF also bound to the endothelium of brain and eye in the primate, but these tissues are not listed in Table III, because the staining was designated as moderate, not strong. Similarly, the HIRMAbGDNF strongly stained neurons and glial cells in brain and spinal cord of humans (Table III) and gave moderate staining of these cells in primates. The HIRMAb-GDNF fusion protein bound to epithelial and mesothelial cells in different tissues in both humans and primates (Table III).

\section{DISCUSSION}

This study demonstrates that single intravenous injections of the HIRMAb-GDNF fusion protein have no adverse effects in 56 Rhesus monkeys subjected to either a 2-week terminal toxicity study or an acute safety study. The plasma pharmacokinetic (PK) profile and tissue cross-reactivity profile are reported. The study establishes the no-observableadverse-effect level (NOAEL) for acute intravenous administration of the HIRMAb-GDNF fusion protein in future human clinical trials. This study is the first such evaluation of a molecular Trojan horse recombinant fusion protein, wherein the Trojan horse is a receptor-specific MAb against an endogenous $\mathrm{BBB}$ receptor, the HIR.

GDNF could be developed as a neurotherapeutic for humans both as an acute, single dose treatment for stroke (4) or as a chronic treatment for conditions such as PD (2) or drug addiction $(6,7)$. Since GDNF does not cross the BBB, this neurotrophin was administered to patients with PD by direct intra-cerebral injection. Following initial open label clinical trials with intra-cerebral GDNF $(16,17)$, a controlled clinical trial with this delivery system did not show clinical benefit (8). However, the design of this clinical trial has been questioned (18). An alternative approach to the delivery of GDNF to brain is the use of IgG-GDNF fusion proteins, wherein the IgG part acts as a molecular Trojan horse to deliver the GDNF to brain via the trans-vascular route. In this respect, the trans-vascular delivery of GDNF is analogous to the brain delivery of LDOPA for the treatment of PD. The subsequent action of LDOPA or GDNF in brain is a function of the regional expression of the target receptor. Although the GDNF receptor, GFR $\alpha 1$, is up-regulated in brain injury (19) or stroke (20), the co-expression of GFR $\alpha 1$ and the c-ret kinase in control brain is highly circumscribed $(21,22)$. An advantage of a trans-vascular delivery of GDNF to brain is that an invasive, neurosurgical procedure is not required.

The trans-vascular delivery of GDNF to brain is possible following the re-engineering of this neurotrophin as a HIRMAb-GDNF fusion protein. This fusion protein traverses the $\mathrm{BBB}$ via receptor-mediated transcytosis (RMT) on the $\mathrm{BBB}$ insulin receptor. The BBB HIR normally serves to mediate the RMT of endogenous insulin $(23,24)$. The HIRMAb binds an exofacial epitope on the HIR, and this binding enables the transport of the antibody across the BBB and into brain (12). The binding of the HIRMAb to the human $\mathrm{BBB}$ and the in vivo $\mathrm{BBB}$ transport of the HIRMAb in the Rhesus monkey have been demonstrated previously for

Table II. Pharmacokinetic Parameters

\begin{tabular}{|c|c|c|c|c|}
\hline \multirow[b]{2}{*}{ Parameter } & \multirow[b]{2}{*}{ units } & \multicolumn{3}{|c|}{ HIRMAb-GDNF dose } \\
\hline & & $0.4 \mathrm{mg} / \mathrm{kg}$ & $2.0 \mathrm{mg} / \mathrm{kg}$ & $10.0 \mathrm{mg} / \mathrm{kg}$ \\
\hline A1 & $\% \mathrm{ID} / \mathrm{mL}$ & $0.113 \pm 0.022$ & $0.123 \pm 0.026$ & $0.311 \pm 0.132$ \\
\hline k1 & $\min ^{-1}$ & $0.114 \pm 0.022$ & $0.114 \pm 0.021$ & $0.449 \pm 0.112$ \\
\hline $\mathrm{A} 2$ & $\% \mathrm{ID} / \mathrm{mL}$ & $0.00645 \pm 0.00095$ & $0.00477 \pm 0.00076$ & $0.00315 \pm 0.00040$ \\
\hline $\mathrm{k} 2$ & $\min ^{-1}$ & $0.00228 \pm 0.00021$ & $0.00154 \pm 0.00022$ & $0.00133 \pm 0.00021$ \\
\hline MRT & $\min$ & $327 \pm 32$ & $484 \pm 77$ & $583 \pm 104$ \\
\hline Vc & $\mathrm{mL} / \mathrm{kg}$ & $271 \pm 54$ & $256 \pm 53$ & $107 \pm 43$ \\
\hline Vss & $\mathrm{mL} / \mathrm{kg}$ & $2767 \pm 321$ & $3789 \pm 561$ & $6372 \pm 993$ \\
\hline AUCss & $\% \mathrm{ID} \cdot \min / \mathrm{mL}$ & $3.83 \pm 0.32$ & $4.19 \pm 0.41$ & $3.06 \pm 0.34$ \\
\hline AUCss & $\mathrm{ug} \bullet \min / \mathrm{mL}$ & $47.4 \pm 4.0$ & $255 \pm 25$ & $916 \pm 101$ \\
\hline CL & $\mathrm{mL} / \mathrm{kg} / \mathrm{min}$ & $8.45 \pm 0.72$ & $7.84 \pm 0.78$ & $10.94 \pm 1.24$ \\
\hline BW & $\mathrm{kg}$ & $3.10 \pm 0.32$ & $3.05 \pm 0.20$ & $2.99 \pm 0.18$ \\
\hline Dose & $\mu \mathrm{g}$ & $1238 \pm 126$ & $6090 \pm 391$ & $29930 \pm 1802$ \\
\hline No. animals & & 6 & 6 & 10 \\
\hline
\end{tabular}




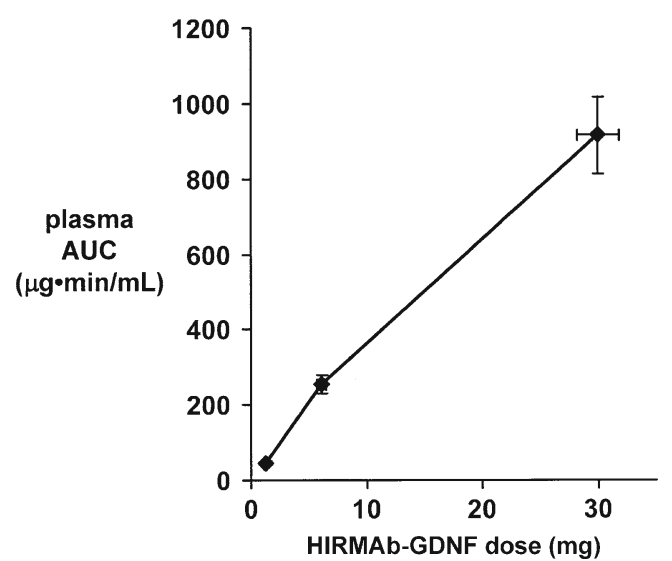

Fig. 3. Linear relationship between the plasma AUC and the dose of HIRMAb-GDNF fusion protein. Data are mean \pm S.D. $(n=6-10$ animals/group).

the murine, chimeric, and humanized form of the antibody $(12,25,26)$. In contrast, there is no $\mathrm{BBB}$ receptor for a neurotrophin such as GDNF, and GDNF does not cross the BBB (5). Similar to the HIRMAb, the HIRMAb-GDNF fusion protein also crosses the $\mathrm{BBB}$ in the adult primate, and the brain uptake is $0.55 \pm 0.04 \%$ of injected dose (ID) per brain (unpublished observations). Given a primate body weight of $5 \mathrm{~kg}$ and a fusion protein injection dose of $0.2 \mathrm{mg} / \mathrm{kg}$, the brain concentration of the HIRMAb-GDNF fusion protein increases to $55 \mathrm{ng} / \mathrm{gram}$. Since the fusion protein is approximately $20 \%$ GDNF (4), the brain concentration of exogenous GDNF is increased to $11 \mathrm{ng} / \mathrm{gram}$ with a $0.2 \mathrm{mg} / \mathrm{kg}$ dose of fusion protein. The endogenous GDNF concentration in human brain is $0.68 \mathrm{ng} / \mathrm{gram}$ in the putamen
(27). Therefore, an injection dose of HIRMAb-GDNF fusion protein of only $0.2 \mathrm{mg} / \mathrm{kg}$ causes an approximately 15 -fold increase in putamen GDNF. Elevations in striatal GDNF of this magnitude are neuroprotective in experimental PD (28).

The potential toxicity of administration of large doses of the HIRMAb-GDNF fusion protein was examined in the present study, and the fusion protein was found to have a remarkable safety profile (Results). High doses of a monoclonal antibody against the insulin receptor could have either agonist or antagonist properties at the insulin receptor. In this event, administration of the HIRMAb, or an HIRMAb fusion protein that retains high affinity for the HIR, could cause either hypo-glycemia or hyper-glycemia. However, the present study shows no change in the plasma glucose, even in the high dose treatment group (Fig. 1). Plasma concentrations of the HIRMAb-GDNF fusion protein as high as 39 $\mathrm{ug} / \mathrm{mL}$ (Table II), which is $>200 \mathrm{nM}$, have no effect on glycemic control (Fig. 1). The absence of an effect on circulating glucose is attributed to the fact that the bulk of insulin-responsive tissues in skeletal muscle and fat are perfused by continuous endothelium, which does not express an insulin receptor (29). Insulin, which is only $5 \mathrm{kDa}$, crosses the endothelium in peripheral tissues passively through pores (30). The passive diffusion across peripheral endothelial barriers of the $190 \mathrm{kDa}$ HIRMAb-GDNF fusion protein is more restrictive. In contrast, the expression of the insulin receptor on the BBB enables ligands, such as insulin or the HIRMAb, to rapidly enter brain within minutes of intravenous administration $(12,24)$.

The present study was designed to support future clinical trials of the acute administration of the HIRMAb-GDNF fusion protein to humans. GDNF is a potent neuroprotective agent in cerebral ischemia, as topical administration of GDNF to ischemic brain reduces the size of the cerebral infarct
A

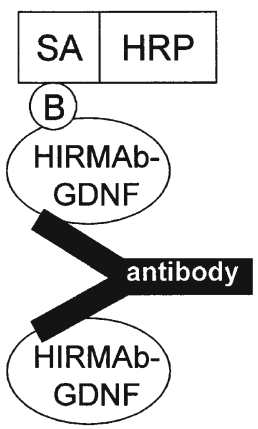

B

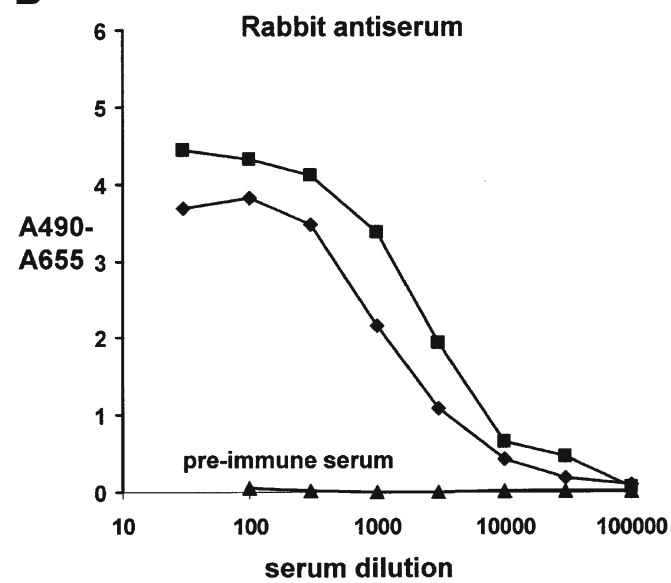

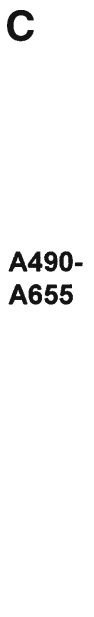

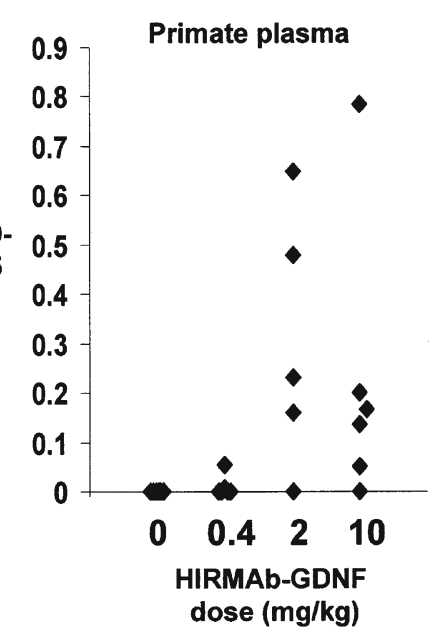

Fig. 4. (A) Structure of the 2-site ELISA for detection of antibodies against the HIRMAb-GDNF fusion protein. The HIRMAb or the HIRMAb-GDNF fusion protein is used as the capture reagent, and the biotinylated HIRMAb-GDNF fusion protein is used as the detector reagent, along with a complex of streptavidin (SA) and horseradish peroxidase (HRP); the biotin moiety is designated, 'B'. (B) Absorbance at various dilutions of a rabbit antiserum prepared against the HIRMAb-GDNF fusion protein, and the respective pre-immune serum (triangles). Either the HIRMAb (squares) or the HIRMAb-GDNF fusion protein (diamonds) was used as the capture reagent. Data are means of duplicates that varied $<10 \%$. (C) Absorbance at 1:50 dilutions of Rhesus monkey plasma taken at day 13, following the administration of $0,0.4,2$, or $10 \mathrm{mg} / \mathrm{kg}$ of the HIRMAb-GDNF fusion protein every $12 \mathrm{~h}$ for 5 consecutive doses over days $1-3$ of the study. The total dose of fusion protein given over the 60 -hr period was $0,2,10$, and $50 \mathrm{mg} / \mathrm{kg}$ (Methods). A significant immune reaction is registered with an (A490-A655) signal $>0.3$. 
Table III. Human and Rhesus Monkey Tissue Cross-Reactivity of HIRMAb-GDNF Fusion Protein

\begin{tabular}{|c|c|c|}
\hline & Human & Rhesus monkey \\
\hline $\begin{array}{l}\text { Number of tissues } \\
\text { examined }\end{array}$ & 35 & 34 \\
\hline $\begin{array}{l}\text { Number of donors } \\
\text { Examined }\end{array}$ & 3 & 2 \\
\hline Strongly reactive on & cerebrum & \\
\hline Neurons and glial cells & $\begin{array}{l}\text { cerebellum } \\
\text { spinal cord }\end{array}$ & \\
\hline Epithelial cells & $\begin{array}{l}\text { eye } \\
\text { placenta } \\
\text { breast } \\
\text { ovary } \\
\text { prostate } \\
\text { testis } \\
\text { thyroid gland } \\
\text { ureter } \\
\text { uterus }\end{array}$ & $\begin{array}{l}\text { adrenal gland } \\
\text { placenta } \\
\text { breast } \\
\text { ovary } \\
\text { prostate } \\
\text { testis } \\
\text { thyroid gland } \\
\text { ureter } \\
\text { pancreas } \\
\text { skin } \\
\text { urinary bladder }\end{array}$ \\
\hline Endothelial cells & $\begin{array}{l}\text { cerebrum } \\
\text { cerebellum } \\
\text { spinal cord } \\
\text { eye }\end{array}$ & \\
\hline Mesothelial cells & $\begin{array}{l}\text { spleen } \\
\text { Oviduct } \\
\text { testis }\end{array}$ & $\begin{array}{l}\text { spleen } \\
\text { small intestine } \\
\text { liver } \\
\text { urinary bladder } \\
\text { uterus }\end{array}$ \\
\hline $\begin{array}{l}\text { Hematopoietic cells } \\
\text { Smooth muscle cells }\end{array}$ & $\begin{array}{l}\text { bone marrow } \\
\text { cerebrum } \\
\text { eye }\end{array}$ & bone marrow \\
\hline
\end{tabular}

The above tissues exhibited strong, frequent staining at the high concentration $(15 \mathrm{ug} / \mathrm{mL})$ of biotinylated HIRMAb-GDNF.

$(4,31)$. The GDNF must be given trans-cranially in experimental stroke, because (a) GDNF does not cross the BBB, and (b) the BBB is intact for at least $6 \mathrm{~h}$ following stroke (32), during which neuroprotection is still possible. Although the $\mathrm{BBB}$ does become permeable in stroke (33), this disruption occurs $12-24 \mathrm{~h}$ after stroke, when it is no longer possible to rescue ischemic neurons. The intra-cerebral injection of the HIRMAb-GDNF fusion protein in a rat middle cerebral artery occlusion (MCAO) model caused a $90 \%$ reduction in stroke volume (4). The HIRMAb-GDNF fusion protein was administered in the rat MCAO model via a trans-cranial route, because the HIRMAb does not react with the rodent insulin receptor. No surrogate antibody could be used, since there is no known MAb against the rodent insulin receptor that could be used as a BBB molecular Trojan horse.

The HIRMAb does cross-react with the insulin receptor of Old World primates, such as the Rhesus monkey, but not the more distant New World primate, such as the squirrel monkey (12). Immunocytochemistry of Rhesus monkey brain using the HIRMAb as the primary antibody shows high binding of the HIRMAb to the $\mathrm{BBB}$ insulin receptor, which parallels other studies showing high binding of insulin (23), or the HIRMAb (12), to capillaries isolated from human autopsy brain. The high binding of the HIRMAb to the human and Rhesus monkey insulin receptor is further corroborated by the tissue cross-reactivity (TCR) immunocytochemistry reported in the present study (Table III). The TCR study employed a biotinylated form of the HIRMAbGDNF fusion protein so as to avoid non-specific immune reactions caused by binding of an anti-human $\mathrm{IgG}$ secondary antibody to the endogenous $\mathrm{IgG}$ in human or primate tissues. The HIRMAb-GDNF fusion protein retained high affinity binding for both the HIR and the GFR $\alpha 1$ following biotinylation (Methods). The endothelium of brain and spinal cord gave strong immune staining with the HIRMAb-GDNF in human tissues (Table III).

The Rhesus monkey was used to assess the safety and potential toxicity of the HIRMAb-GDNF fusion protein owing to the limited species cross-reactivity of the HIRMAb. The present study shows no adverse events are caused by the serial administration of five doses of the HIRMAb-GDNF fusion protein over the range of $0.4-10 \mathrm{mg} / \mathrm{kg}$ for a single injection, or $2-50 \mathrm{mg} / \mathrm{kg}$ over a $60-\mathrm{hr}$ period (Results). Following the repeated administration of five consecutive doses over a $60 \mathrm{hr}$ period of the HIRMAb-GDNF fusion protein, a measureable immune response, defined as a (A490-A655) signal above a cutoff of 0.3 , was observed in $25 \%$ of the animals in the highest two dosage groups (Fig. 4C). This immune response, at 1:50 dilutions of primate plasma, was minimal compared to that of high dilutions of a rabbit antiserum prepared against the HIRMAb-GDNF fusion protein (Fig. 4B). The immune signal for either the rabbit antiserum, or the primate plasma samples, was measured with either the HIRMAb or the HIRMAb-GDNF fusion protein as the capture reagent. A comparable immune signal was observed for either the rabbit antiserum or the primate plasma samples, although the immune signal was slightly higher when the HIRMAb was plated as the capture reagent, as compared to the HIRMAb-GDNF fusion protein, for the rabbit antiserum (Fig. 4B), or the primate plasma samples. These observations suggest there is not a significant immune response to the GDNF part of the HIRMAb-GDNF fusion protein. Immune tolerance to $\mathrm{IgG}$ fusion proteins is induced by amino acid sequences within the constant region of the $\operatorname{IgG}$ moiety called Tregitopes (34).

The analysis of the plasma PK profile of the HIRMAbGDNF fusion protein was enabled by the development of a specific 2-site ELISA outlined in Fig. 2A. The HIR ECD is used as the capture reagent, and an anti-GDNF antibody is used as the detection reagent. Only intact HIRMAb-GDNF fusion protein is detected by the assay, as the HIRMAb alone is not reactive in the assay (Methods). The plasma concentrations of the HIRMAb-GDNF (Table I) were analyzed with a 2-compartmental model (Methods) to yield the PK parameters in Table II. The PK analysis shows that the rate of clearance of the HIRMAb-GDNF fusion protein from the central compartment is rapid, similar to that of a small molecule, and different from the clearance of a classical MAb-therapeutic. The extravascular volume of distribution, Vss, of a monoclonal antibody is generally similar to the central volume of distribution, Vc, owing to limited egress of the MAb from plasma to the extra-vascular space. However, in the case of the HIRMAb-GDNF fusion protein, the Vss is 3,000 to $6,000 \mathrm{~mL} / \mathrm{kg}$ and is 10 -fold to 60 -fold greater than the Vc (Table II). The systemic clearance rate, CL, is $8-10 \mathrm{~mL} / \mathrm{kg} /$ min (Table II), which is comparable to the systemic clearance, 
$27 \mathrm{~mL} / \mathrm{kg} / \mathrm{min}$, of a small molecule in the Rhesus monkey (35). The systemic clearance of the HIRMAb-GDNF fusion protein is higher than previous estimates for the systemic clearance of the HIRMAb-neurotrophin fusion protein, which is about $1.0 \mathrm{~mL} / \mathrm{kg} / \mathrm{min}$ in a 5-year old adult Rhesus monkey (13). In the present study, the PK analysis was performed on Rhesus monkeys of $2.8-3.3 \mathrm{~kg}$ body weight (Methods), which are pre-pubescent animals (36). Younger animals express higher levels of insulin receptor, transport circulating insulin, and possibly the HIRMAb at faster rates (37).

In conclusion, these studies show there are no adverse events associated with the acute administration of large doses of the HIRMAb-GDNF fusion protein, and establish a NOAEL for future human clinical trials. If further drug development of the HIRMAb-GDNF fusion protein is successful, it would be possible to re-engineer other protein pharmaceuticals for targeted drug delivery across the human BBB with the molecular Trojan horse technology

\section{ACKNOWLEDGEMENTS}

This research was supported by NIH grant R44-NS044654. The authors are indebted to Drs. Yun Zhang and Yufeng Zhang for technical support, to MPI Research, Inc., for participation in the GLP primate studies, to Charles Rivers Laboratories for the GLP tissue cross-reactivity study.

Open Access This article is distributed under the terms of the Creative Commons Attribution Noncommercial License which permits any noncommercial use, distribution, and reproduction in any medium, provided the original author(s) and source are credited.

\section{REFERENCES}

1. Lin LF, Doherty DH, Lile JD, Bektesh S, Collins F. GDNF: a glial cell line-derived neurotrophic factor for midbrain dopaminergic neurons. Science. 1993;260:1130-2.

2. Lapchak PA, Miller PJ, Collins F, Jiao S. Glial cell line-derived neurotrophic factor attenuates behavioural deficits and regulates nigrostriatal dopaminergic and peptidergic markers in 6-hydroxydopamine-lesioned adult rats: comparison of intraventricular and intranigral delivery. Neuroscience. 1997;78:61-72.

3. Bohn MC. Motoneurons crave glial cell line-derived neurotrophic factor. Exp Neurol. 2004;190:263-75.

4. Boado RJ, Zhang Y, Wang Y, Pardridge WM. GDNF fusion protein for targeted-drug delivery across the human blood-brain barrier. Biotechnol Bioeng. 2008;100:387-96.

5. Kastin AJ, Akerstrom V, Pan W. Glial cell line-derived neurotrophic factor does not enter normal mouse brain. Neurosci Lett. 2003;340:239-41.

6. He DY, McGough NN, Ravindranathan A, Jeanblanc J, Logrip ML, Phamluong $\mathrm{K}$, et al. Glial cell line-derived neurotrophic factor mediates the desirable actions of the anti-addiction drug ibogaine against alcohol consumption. J Neurosci. 2005;25:61928.

7. Ronand D, Janak PH. GDNF and addiction. Rev Neurosci. 2005; $16: 277-85$

8. Lang AE, Gill S, Patel NK, Lozano A, Nutt JG, Penn R, et al. Randomized controlled trial of intraputamenal glial cell linederived neurotrophic factor infusion in Parkinson disease. Ann Neurol. 2006;59:459-66.
9. Salvatore MF, Ai Y, Fischer B, Zhang AM, Grondin RC, Zhang $\mathrm{Z}$, et al. Point source concentration of GDNF may explain failure of phase II clinical trial. Exp Neurol. 2006;202:497-505.

10. Pardridge WM. The blood-brain barrier: bottleneck in brain drug development. NeuroRx. 2005;2:3-14.

11. Pardridge WM. Re-engineering biopharmaceuticals for delivery to brain with molecular Trojan horses. Bioconjug Chem. 2008;19:1327-38.

12. Pardridge WM, Kang YS, Buciak JL, Yang J. Human insulin receptor monoclonal antibody undergoes high affinity binding to human brain capillaries in vitro and rapid transcytosis through the blood-brain barrier in vivo in the primate. Pharm Res. 1995;12:807-16.

13. Boado RJ, Zhang Y, Pardridge WM. Genetic engineering, expression, and activity of a fusion protein of a human neurotrophin and a molecular Trojan horse for delivery across the human blood-brain barrier. Biotechnol Bioeng. 2007;97:1376-86.

14. Garman RH. Evaluation of large-sized brains for neurotoxic endpoints. Toxicol Pathol. 2003;31(Suppl):32-43

15. FDA. Points to consider in the manufacture and testing of monoclonal antibody products for human use (1997). U.S. Food and Drug Administration Center for Biologics Evaluation and Research. J Immunother. 1997;20:214-43.

16. Gill SS, Patel NK, Hotton GR, O'Sullivan K, McCarter R, Bunnage $\mathrm{M}$, et al. Direct brain infusion of glial cell line-derived neurotorphic factor in Parkinson disease. Nat Med. 2003;5:589-95.

17. Slevin JT, Gerhardt GA, Smith CD, Gash DM, Kryscio R, Young B. Improvement of bilateral motor functions in patients with Parkinson disease through the unilateral intraputaminal infusion of glial cell line-derived neruotrophic factor. J Neurosurg. 2005;102:216-22.

18. Hutchinson M, Gurney S, Newson R. GDNF in Parkinson disease: an object lesson in the tyranny of type II. J Neurosci Methods. 2007;163:190-2

19. Cheng Q, DiLiberto V, Caniglia G, Giuseppa M. Time-course of GDNF and its receptor expression after brain injury in the rat. Neurosci Lett. 2008;439:24-9.

20. Sarabi A, Chang CF, Wang Y, Hoffer BJ, Morales M. Time course study of GFR $\alpha-1$ expression in an animal model of stroke. Exp Neurol. 2001;170:283-9.

21. Tanya CD, Gundlach AL. Localization of GDNF/neuturin (c-ret, GFR $\alpha-1$ and $\alpha-2$ ) mRNAs in postnatal rat brain: differential regional and temporal expression in hippocampus, cortex and cerebellum. Mol Brain Re. 1999;73:151-71.

22. Yang C, Hutto D, Sah DWY. Distribution of GDNF family receptor $\alpha 3$ and RET in rat and human non-neural tissues. J Mol Hist. 2006;37:69-77.

23. Pardridge WM, Eisenberg J, Yang J. Human blood-brain barrier insulin receptor. J Neurochem. 1985;44:1771-8.

24. Duffy KR, Pardridge WM. Blood-brain barrier transcytosis of insulin in developing rabbits. Brain Res. 1987;420:32-8.

25. Coloma MJ, Lee HJ, Kurihara A, Landaw EM, Boado RJ, Morrison SL, et al. Transport across the primate blood-brain barrier of a genetically engineered chimeric monoclonal antibody to the human insulin receptor. Pharm Res. 2000;17:266-74.

26. Boado RJ, Zhang Y, Zhang Y, Pardridge WM. Humanization of anti-human insulin receptor antibody for drug targeting across the human blood-brain barrier. Biotechnol Bioeng. 2007;96:381-91.

27. Michel TM, Frangou S, Camara S, Thiemeyer D, Jecel J, Tatschner $\mathrm{T}$, et al. Altered glial cell line-derived neurotrophic factor (GDNF) concentrations in the brain of patients with depressive disorder: a comparative post-mortem study. Eur Psychiat. 2008;23:413-20.

28. Eslamboli A, Georgievska B, Ridley RM, Baker HF, Muzyczka $\mathrm{N}$, Burger $\mathrm{C}$, et al. Continuous low-level glial cell line-derived neurotrophic factor delivery using recombinant adeno-associated viral vectors provides neuroprotection and induces behavioral recovery in a primate model of Parkinson's disease. J Neurosci. 2005;25:769-77.

29. Zhang Y, Schlachetzki F, Pardridge WM. Global non-viral gene transfer to the primate brain following intravenous administration. Mol Ther. 2003;7:11-8.

30. Steil GM, Ader M, Moore DM, Rebrin K, Bergman RN Transendothelial insulin transport is not saturable in vivo. No 
evidence for a receptor-mediated process. J Clin Invest. 1996;97:1497-503.

31. Kitagawa H, Hayashi T, Mitsumoto Y, Koga N, Itoyama Y, Abe $\mathrm{K}$. Reduction of ischemic brain injury by topical application of glial cell line-derived neurotrophic factor after permanent middle cerebral artery occlusion in rats. Stroke. 1998;29:141722.

32. Belayev L, Busto R, Zhao W, Ginsberg MD. Quantitative evaluation of blood-brain barrier permeability following middle cerebral artery occlusion in rats. Brain Res. 1996;739:88-96.

33. Latour LL, Kang DW, Ezzeddine MA, Chalela JA, Warach S. Early blood-brain barrier disruption in human focal brain ischemia. Ann Neurol. 2004;56:468-77.
34. DeGroot AS, Moise L, McMurry JA, Wambre E, Van Overtvelt L, Moingeon $\mathrm{P}$, et al. Activation of natural regulatory $\mathrm{T}$ cells by $\mathrm{IgG}$ Fc-derived peptide "Tregitopes". Blood. 2008;112:3303-11.

35. Renbarger J, Aleksic A, McGuffey L, Dauser R, Berg S, Blaney S. Plasma and cerebrospinal fluid pharmacokinetics of SU5416 after intravenous administration in nonhuman primates. Cancer Chemother Pharmacol. 2004;53:39-42.

36. Wilenand R, Naftolin F. Age, weight and weight gain in the individual pubertal female rhesus monkey (Macaca mulatta). Biol Reprod. 1976;15:356-60.

37. Frank HJ, Jankovic-Vokes T, Pardridge WM, Morris WL. Enhanced insulin binding to blood-brain barrier in vivo and to brain microvessels in vitro in newborn rabbits. Diabetes. 1985;34:728-33. 